\section{Barbara Strzałkowska}

Uniwersytet Kardynała Stefana Wyszyńskiego w Warszawie

e-mail: bstrzalkowska@wp.pl

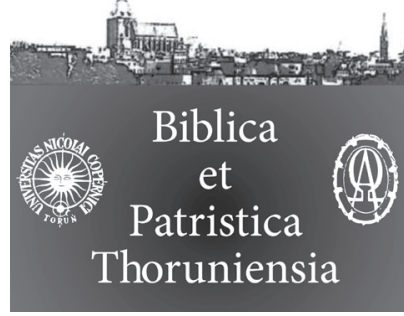

8 (2015) 2 ISSN 1689-5150

DOI: http://dx.doi.org/10.12775/BPTh.2015.007

\title{
Przemoc wobec kobiety w świetle przepisów Tory?
}

\section{Violence against women in the light of the laws of the Torah?}

Streszczenie. Przemoc (także wobec kobiet) - choć nie dominuje w Biblii - to jednak jest w niej obecna. W Pięcioksięgu, który jest przedmiotem zainteresowania niniejszego artykułu, przemoc pojawia się już w historii początków, wraz z pierwszym bratobójstwem (historią Kaina i Abla; Rdz 4), a następnie przybiera różne formy: są w Torze opisy przemocy mężczyzn wobec mężczyzn; a także opisy przemocy mężczyzn wobec kobiet (gwałt Diny, Rdz 34); jest także przemoc kobiet wobec kobiet (Sarah i Hagar); ale także - co może zaskakujące - przemoc kobiet wobec mężczyzn (historia córek Lota; $\operatorname{Rdz} 19)$.

Szczególnym zagadnieniem związanym z przemocą w Pięcioksięgu są aspekty prawne. Biblia nie podaje własnej definicji przemocy, choć wszelkie akty przemocy (w niektórych przypadkach omówione szczegółowo; także te dotyczące kobiet) są w niej wyraźnie potępione, a nawet obłożone sankcjami. Przepisy biblijne w żadnym miejscu nie zachęcają do przemocy (w tym do przemocy wobec kobiet), nie propagują przemocy ani jej nie usprawiedliwiają. Pięcioksiąg zawiera różne regulacje dotyczące kobiet: począwszy od Dekalogu (Wj 20 i Pwt 5) przez prawo karne z Księgi Wyjścia oraz prawo czystości i świętości zawarte w Księdze Kapłańskiej, aż po rozmaite szczegółowe przepisy z Księgi Powtórzonego Prawa. Regulują one niektóre aspekty życia kobiet (związane głównie ze sferą seksualną i rodziną, ale nie tylko), także dotyczące przemocy.

$\mathrm{Z}$ analizy tych tekstów legislacyjnych można wyciągnąć kilka wniosków: 1. Wszystkie przepisy w Torze są pisane przez i dla mężczyzn (to mężczyźni byli odpowiedzialni za przestrzeganie prawa). 2. Wszystkie $z$ tych przepisów Tory powinny być rozumiane w kontekście starożytnego patriarchalnego społeczeństwa i kultury całego Bliskiego Wschodu. 3. Nie ma w Torze szczegółowych przepisów dla kobiet popełniających jakiekolwiek akty przemocy, więc wydaje się, że kobiety nie ponosiły żadnych konsekwencji za swoje czyny (co wskazuje, że przepisy prawne w Pięcioksięgu nie regulowały wszystkich aspektów ludzkiego życia). 4. W samej Biblii nie ma dowodów na to, by przepisy Tory (również te dotyczące kobiet) były kiedykolwiek ściśle przestrzegane. 
Abstract. Violence (also against women) - though not dominant in the Bible - it is nevertheless present in it. In the Pentateuch, on which this article focuses, violence occurs in the history of the origins, with the first fratricide (history of Cain and Abel; Genesis 4) and then takes many forms: there are descriptions of men's violence against men; there are also descriptions of men's violence against women (rape of Dinah; Genesis 34); there is also women's violence against women (Sarah and Hagar); but also surprisingly - there is women's violence against men (the story of Lot's daughters; Genesis 19).

A particular issue related to violence in the Pentateuch are legal aspects. The Bible itself does not give its own definition of violence, although all acts of violence (in some cases discussed in detail; also regarding women) are condemned in the Bible and even levied on specific sanctions. The biblical legislation does not encourage to violence (including this against women), it does not propagate violence, nor does allow it. Pentateuch contains various laws concerning women: beginning with the Ten Commandments (Exodus 20 and Deuteronomy 5), and then also the penal laws from the Book of Exodus along with the laws of purity and holiness from the Book of Leviticus; and also various detailed laws from the Book of Deuteronomy. They regulate some aspects of women's lives (mainly related to sexual activity and family, but not limited to it), also concerning laws against some acts of violence.

Several conclusions can be drawn from the legislation texts analysis: 1 . All the laws in the Torah are written by and for men (men were responsible for observing the law). 2. All of these regulations of the Torah should be understood in the context of the ancient patriarchal society and in the culture of the entire Middle East in antiquity. 3. There are no specific rules for women committing acts of violence in the Torah, thus it seems there were no consequences for women for any act of violence (which indicates that these laws do not regulate all aspects of human life). 4. In the Bible itself there is no evidence that the regulations of the Torah (also concerning women) were ever strictly observed.

Słowa kluczowe: Pięcioksiąg (Tora); przemoc; kobiety; przemoc w Pięcioksięgu; prawodawstwo biblijnego Izraela dotyczące kobiet.

Keywords: Pentateuch (the Torah); violence; women; violence in the Pentateuch; legislation concerning women in ancient Israel.

$\mathrm{T}$ ematyka dotycząca przemocy w Biblii, w tym przemocy wobec kobiet ${ }^{1}$, jest bardzo trudna, choć podejmowana co jakiś czas w kontekście refleksji teo-

1 Na temat przemocy wobec kobiet w Biblii zob. np. cały tom: La violence envers les femmes: Concilium: Revue internationale de théologie 252/1994 (w tym tomie m.in. artykuł: E. Schüssler-Fiorenza, La violence contre les femmes, s. 7-25); oraz: H.C. Washington, Violence and the Construction of Gender in the Hebrew Bible, s. 324-363; Ch.A. Kirk-Duggan, 
logicznej nad poszczególnymi częściami i księgami Pisma Świętego (Starego i Nowego Testamentu) ${ }^{2}$. Tematyka ta należy do trudnych nie tylko ze względu na sam przedmiot, lecz także ze względu na postawy badaczy, którzy, podejmując ten temat, narażają się niejednokrotnie na dwojakiego typu niebezpieczeństwo: zbytniego pobłażania tekstowi biblijnemu (gdy usprawiedliwia się wszelką obecną w tym tekście niesprawiedliwość, także tę wobec kobiet), albo zbytniego oskarżania tekstu biblijnego (tak, jak czasem dzieje się z przedstawicielami feministycznej refleksji nad Biblią, którzy widzą w niej jedynie narzędzie do usprawiedliwiania przemocy wobec kobiet; nie tylko w starożytności, ale nawet dziś). Obie postawy mówią więcej o tych, którzy tekst interpretują niż o Biblii i jej wielowymiarowości. Dobrze, że tematyka dotycząca przemocy w Biblii jest podejmowana także w refleksji naukowej, pomaga to bowiem ukazać złożoność tego tematu.

W Biblii - choć nie dominuje - to jednak jest obecna przemoc, i to już od pierwszych jej kart. Kardynał Gianfranco Ravasi we wstępie do włoskiego wydania Biblii Jerozolimskiej ${ }^{3}$, nawiązując do średniowiecznego egzegety Ruperta z Deutz, zauważył, że lektura Biblii przypomina czasem walkę ze świętym tekstem (wł. lotta corpo al corpo col libro sacro). Człowiek, który czyta Pismo Święte, spotyka w nim wojny, krew, niesprawiedliwość, cierpienie i przemoc, w miejsce spokoju, wyciszenia, modlitwy. Kardynał tłumaczył: Biblia jest miejscem spotkania Boga i człowieka ${ }^{4}$. Od takiej kondycji człowieka Bóg wychodzi i w takim miejscu zaczyna historię zbawienia.

Pregnant Passion. Gender, Sex, and Violence in the Bible; J.T. Fitzgerald, Domestic violence in the Ancient World, s. 101-121; Caryn A. Reeder, Wives and Daughters: Women, Sex, and Violence, s. 122-141; Fragile Dignity. Intercontextual Conversations on Scriptures, Family, and Violence.

2 O przemocy w Biblii zob. np.: R. Girard, La Violence et le sacré; N. Lohfink, Gewalt und Gewaltlosigkeit im Alten Testament; T. Römer Dieu obscur: le sexe, la cruauté et la violence; J. Bekkenkamp, Y. Sherwood, Sanctified Aggression: Legacies of Biblical and Post Biblical Vocabularies of Violence; A. Wénin, Au-delà de la violence, quelle justice?, s. 433-456; La violència en la Bíblia. W polskiej literaturze zob. np.: W. Chrostowski, Przemoc i gwałt w Piśmie Świętym, s. 89-109; W. Pikor, Bóg wobec przemocy człowieka w Rdz 1-11, s. 11-31; W. Chrostowski, Zjawiska przemocy i gwałtu w Starym Testamencie jako przejawy zapośredniczenia poznania Boga, s. 89-102.

3 La Bibbia di Gerusalemme (por. Presentazione, s. 5-7).

4 Ibidem (Presentazione, s. 6). 


\section{Przemoc w Pięcioksięgu. Prawodawstwo dotyczące przemocy}

W pierwszej części Biblii Starego Testamentu - w Pięcioksięgu, który będzie przedmiotem refleksji niniejszego artykułu - przemoc pojawia się już w czwartym rozdziale Księgi Rodzaju: wraz z pierwszym bratobójstwem, historią Kaina i Abla $(\operatorname{Rdz} 4,1-16)^{5}$. A także coraz liczniej w kolejnych rozdziałach, co autor biblijny ukazuje niejako jako konsekwencję kondycji człowieka po grzechu $(\operatorname{Rdz} 3)^{6}$. Przemoc ta może przyjmować różne formy, w tym także przemocy wobec kobiet - zarówno fizycznej, jak i psychicznej - zarówno ze strony mężczyzn, jak również ze strony innych kobiet.

W Pięcioksięgu są obecne opisy przemocy mężczyzn wobec mężczyzn (nie tylko historia Kaina i Abla, ale również w innym wymiarze przemoc w historii Noego i jego synów, m.in. Chama, od którego pochodzi określenie „chamskie zachowanie"7 - Rdz $9^{8}$ ); są także opisy przemocy mężczyzn wobec kobiet (np. gwałt zadany Dinie, córce Jakuba i Lei, przez Sychema, syna Chamora Chiwwity - Rdz $34^{9}$ ); są opisy przemocy kobiet wobec kobiet (np. historia wyrzuconej

5 Perykopa mówiąca o historii Kaina i Abla (i pierwszej przemocy) doczekała się szerokiego omówienia; zob. publikacje książkowe, zwłaszcza: P. Gibert, L’espérance de Caïn. La Bible et la violence; ale także: H. Heyde, Kain, der erste Jahwe-Verehrer; R. Brandscheidt, Kain und Abel: Die Sündenfallerzählung des Jahwisten in Gen 4,1-16; oraz najnowsza książka: D. Pérez Gondar, Caín, Abel y la sangre de los justos. Zob. także artykuły: F. Boyer, "Depuis le sang d'Abel". Fraternité, violence et transcendance, s. 53-64; A. Wénin, Caïn: un récit mythique pour explorer la violence, s. 37-53; B. Janowski, Jenseits von Eden: Gen 4,1-16 und die nichtpriesterliche Urgeschichte, s. 137-159; D. Walter, Im Zeichen Kains: Gewalt und Gewaltüberwindung, s. 252-267; A.-L. Zwilling, Caïn versus Abel (Gn 4,1-16), s. 507-516; E. Peels, The world's first murder: violence and justice, s. 19-39; D. Pérez Gondar, Estudio exegético de Gn 4,1-16, s. 5-75. W piśmiennictwie polskim zob. W. Chrostowski. Zawsze istnieje możliwość poprawy, s. 98-111 (Rés.); idem, „Gdzie jest brat twój, Abel?” (Rdz 4,9), s. 195-209; idem, U źródeł przemocy: Kain i Abel (Rdz 4,1-16), s. 5-19 (Sum.); zob. także: S. Łach, Problemy w relacji biblijnej o Kainie i Ablu (Rdz 4,1-17), s. 13-38 (Rés.); J. Lemański, Grzech rodzi się w sercu człowieka (Rdz 4,1-16), s. 33-51.

6 Por. np. E. Haag, Le péché des origines et l'héritage de la violence, s. 13-31.

7 Por. W. Kopaliński, Słownik eponimów czyli wyrazów odimiennych, s. 51.

8 Na temat Rdz 9 zob.: D. Adamczyk, Upadek Chama i jego skutki na podstawie Rdz 9,18-29, s. 7-15, Sum.; W. Chrostowski, Przekleństwo Kanaana (Rdz 9,20-27), s. 169-183 (Rés.); zob. także: G. Cappelletto, Violenza in societa e in famiglia (Gn 6,1-4 e 9,18-29), s. $4-12$.

9 Na temat tego tekstu zob. np.: L.M. Bechtel, What if Dinah is not Raped? (Genesis 34), s. 19-36; P. Noble, A “Balanced” Reading of the Rape of Dinah, s. 173-204; E. Van Wolde, The Dinah Story: Rape or Worse?, s. 225-239; G. Hepner, The Seduction of Dinah and Jacob's 
niewolnicy Hagar - Rdz 21 - co także w pewnych kategoriach można rozumieć jako przemoc wobec kobiety i to z dzieckiem; a wcześniej Hagar niewolnica nie była lojalna wobec swojej pani, Sary - por. Rdz 16 i $21^{10}$ ); ale też - co może nieco zaskakujące - w Pięcioksięgu są opisy przemocy kobiet wobec mężczyzn (np. można tak traktować w jakimś sensie opisany w $\mathrm{Rdz} 19^{11}$ niesławny występek córek Lota, które swego ojca wykorzystały seksualnie, by mieć z nim potomstwo).

Są zatem w Torze opisy przemocy, choć trzeba pamiętać, że wszystkie one należą do mniejszości i nie dominują w tekście pierwszych pięciu ksiąg Biblii, choć oczywiście każą zastanowić się nad kondycją człowieka.

Szczególnym zagadnieniem związanym $\mathrm{z}$ przemocą $\mathrm{w}$ Pięcioksięgu są aspekty prawne: czy $\mathrm{w}$ prawodawstwie Tory $\mathrm{w}$ jakikolwiek sposób sankcjonuje się przemoc w ogóle, w tym przemoc wobec kobiet? Czy wyraźnie potępia się przemoc, także tę wobec kobiet? Czy prawodawstwo Izraela dyskryminowało kobiety? I czy w jakikolwiek sposób dopuszczało przemoc wobec nich?

Żeby przyjrzeć się temu zagadnieniu, dobrze najpierw określić, czym jest przemoc. Współczesna definicja przemocy podawana przez WHO (Światowa Organizacja Zdrowia), przyjęta w roku 1996 i obowiązująca w naszym kręgu kulturowym do tej pory, określa przemoc jako: „Celowe użycie siły fizycznej lub władzy (ang. power), sformułowane jako groźba lub rzeczywiście użyte, skierowane przeciwko samemu sobie, innej osobie, grupie lub społeczności, które albo prowadzi do albo z którym wiąże się wysokie prawdopodobieństwo spowodowania obrażeń cielesnych, śmierci, szkód psychologicznych, wad rozwoju lub braku elementów niezbędnych do normalnego życia i zdrowia (ang. deprivation)"12.

Anguish Reflect, s. 111-135; P.R. Andiñach, Dina, una mujer víctima de violencia sexual y étnica, s. 37-52; J.E. Cook, Rape and Its Aftermath in Genesis 34, s. 209-214; Y. Shemesh, Rape is Rape is Rape: the Story of Dinah and Shechem, s. 2-21; J. Slawik, O przemocy w Starym Testamencie, s. 31-68 (Zsf.).

10 Na temat Hagar zob. np.: I. Fischer, "Va, et sois soumise", dit l'Ange de Dieu à Agar: Répressions contre les femmes dans les textes bibliques, s. 107-114.

11 Por. na jego temat: M. Jackson, Lot's Daughters and Tamar as Tricksters and the Patriarchal Narratives as Feminist Theology, s. 29-46; J. Grossman, "Associative meanings" in the character evaluation of Lot's daughters, s. 40-57.

12 „The intentional use of physical force or power, threatened or actual, against oneself, another person, or against a group or community, that either results in or has a high likelihood of resulting in injury, death, psychological harm, maldevelopment or deprivation". Por. World Report on Violence and Health, s. 5 (na podstawie m.in. dokumentu WHO z 1996 roku: Violence: a Public Health Priority. WHO Global Consultation on Violence and Health). 
Zgodnie z tą definicją, przemoc, dotycząca osób indywidualnych (także samego siebie), grup i społeczności, może mieć wymiar fizyczny i psychiczny, ale dotyczy także wszelkiego typu braków („brak elementów niezbędnych do normalnego życia i zdrowia”). W sposób szczególny może dotyczyć dyskryminacji (także związanych z płcią) i przemocy w relacji władzy (ang. power).

Pozostaje zadać pytanie, czy prawodawstwo biblijnego Izraela w ogóle takie wątki podejmuje? I czy ta nasza współczesna wizja przemocy przystaje do świata biblijnego?

Sama Biblia nie posiada własnej definicji przemocy, choć wszelkie akty przemocy (jeśli są wspominane) są w Biblii przedstawiane negatywnie. W Pięcioksięgu wyrażone to zostało w sposób szczególny w Dekalogu (dwukrotnie: w Wj 20 i Pwt 5), ale i w innych przepisach składających się na przymierze Izraelitów z Bogiem, które zawarte są w czterech z pięciu ksiąg Tory: Wj, Kpł, Lb i Pwt.

Pierwsze prawa Pięcioksięgu, zapisane w $\mathrm{Wj}$, zaczynają się wraz z Dekalogiem, który wyraźnie potępia przemoc w różnych wymiarach: tym najcięższym - לא תִתרָָָח (,Nie będziesz zabijał”; to wyraźne i najbardziej znane w prawodawstwie Izraela potępienie przemocy) i w innych wymiarach: kradzieży (תאנגב - „Nie będziesz kradl”), kłamstwa (Wj 20,16), pożądania rzeczy bliźniego (Wj 20,17). W Dekalogu wyraźnie potępia się przemoc wobec bliźnich, w wymiarze odbierania życia, ale także wszelkiej nieuczciwości, kradzieży, grabieży.

Oczywistą kwestią jest, że w Biblii wszelka przemoc (w niektórych przypadkach szczegółowo omówiona i dotycząca różnych grup społecznych) jest potępiona, a nawet obłożona konkretnymi sankcjami. W żadnym miejscu prawodawstwo nie zachęca do przemocy, nie propaguje ani jej nie usprawiedliwia. Prawo - zgodnie ze zwyczajami - raczej bierze w ochronę grupy słabsze (np. sieroty i wdowy), a nie odwrotnie, a różne sytuacje, które musiały zdarzać się w społeczności biblijnego Izraela, okłada różnymi sankcjami. Dobrym tego przykładem jest prawo karne, zawarte w Księdze Wyjścia. Np. w Wj 21,12-17 mamy prawo karne, precyzujące, że za zabójstwo groziła kara śmierci ${ }^{13}$ (nie dotyczyło to prawo zabójstwa niewolnicy i niewolnika przez swego pana; prawo o niewolnikach i niewolnicach szczegółowo omówione w tym samym rozdziale - 21,1-11 - nie dawało pełnych praw mężczyznom i kobietom, którzy byli niewolnikami ${ }^{14}$; ale prawodawstwo to było analogiczne do innych tego typu na

13 Na temat tego tekstu zob.: M. Anbar (Berstein), L'influence deutéronomique sur le Code de l'Alliance: le cas d'Exode 21:12-17s. 165-166; por. także: J. Lemański, Księga Wyjścia. Wstęp - przekład z oryginału - komentarz, s. 455-459.

14 Na jego temat zob. J. Lemański, Ksiegga Wyjścia, s. 448-455. 
Bliskim Wschodzie, a przecież nawet znacznie później inne zasady dotyczyć będą niewolników niż wolnych choćby w Rzymie ${ }^{15}$ ).

Trzeba jednocześnie powiedzieć jednak, że prawodawstwo biblijnego Izraela nie regulowało wszystkich aspektów życia, nie miało być w założeniu pełnym kodeksem karnym, ani zbiorem wszystkich rozporządzeń prawnych czy zwyczajów, regulujących całe życie społeczności. W tym, co dotyczy przemocy, wyszczególnia $\mathrm{z}$ tego powodu tylko niektóre przypadki wykroczeń. Wzorując się na prawodawstwie innych narodów bliskiego Wschodu (jak choćby na Kodeksie Hammurabiego ${ }^{16}$ ), wszystkie prawa, które zawarte są na kartach Tory, regulowały jedynie najważniejsze aspekty życia społeczności, zbudowanej zupełnie inaczej niż nasza współczesna. Trudno więc spodziewać się, że regulacje te obejmą wszystkie elementy godne potępienia, nawet jeśli wskazywała na nie praktyka. Najogólniej mówiąc: wszelka przemoc, niesprawiedliwość są w Pięcioksięgu potępione. Ale prawodawstwo nie obejmuje wszystkich przypadków przemocy. Zawiera te, które wydawały się najbardziej potrzebne, będące częścią religijnego przymierza z Bogiem (stąd większość praw dotyczy spraw religii i kultu), ale jednocześnie $\mathrm{w}$ tym, co dotyczy regulacji prawnych dotyczących życia społeczności Izraela i zachodzących ewentualnych wypadków przemocy - wyraźnie wszystkie je potępia, dając temu wyraz, także w tym, co dotyczyło kobiet.

\section{Przepisy Tory dotyczące kobiet}

Trzeba podkreślić, że w samych przepisach Pięcioksięgu nie ma prawa bezpośrednio mówiącego o zakazie przemocy wobec kobiet (tak, jak nie ma prawa ogólnie zakazującego przemocy w ogóle), ale zawiera różne wątki potępiające przemoc w jej wielorakich aspektach, a także w tym, co dotyczy kobiet. Prawo Tory nie skupia się jakoś szczególnie na kwestiach kobiet (czy samo to może być wyrazem przemocy i dyskryminacji? - z pewnością nie!), ale rozważając głównie prawa dotyczące kultu, choć i niektórych aspektów życia społecz-

15 Na temat niewolnictwa w Biblii oraz świecie grecko-rzymskim zob.: M.A. Dandamayev, Slavery (Ancient Near East/ Old Testament), s. 58-65; oraz S. Scott Bartchy, Slavery (Greco-Roman New Testament), s. 65-73. Por także: I. Mendelsohn, Slavery in the Ancient Near East; I. Cardellini, Die biblischen „Sklaven” - Gesetze; Th. Wiedemann, Greek and Roman Slavery; S.R. Joshel. Slavery in the Roman World.

16 Na temat Kodeksu Hammurabiego i jego relacji do prawodawstwa biblijnego Izraela zob.: M. David, The Codex Hammurabi and its Relation, s. 149-178; D.P. Wright, The Laws of Hammurabi as a Source, s. 11-87. 
ności Izraela, wśród tych ostatnich zawiera różne prawa, która także kobiet dotyczyły ${ }^{17}$.

W tym, co odnosi się do kobiet, pierwsze wzmianki prawodawstwa Tory znajdują się w Dekalogu ${ }^{18}$ (Wj 20), we wspomnianych przykazaniach zakazujących przemocy jest również obecne przykazanie wzmiankujące kobiety (Wj $20,17)^{19}$ :

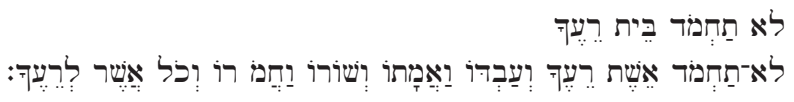

„Nie będziesz pożądał domu bliźniego twego.

Nie będziesz pożądał żony bliźniego twego, ani jego niewolnika, ani jego niewolnicy, ani jego wołu, ani jego osła, ani żadnej rzeczy, która należy do bliźniego twego".

Kobieta $\mathrm{w}$ tym rozporządzeniu znajduje się pomiędzy domem bliźniego a niewolnikiem, potem niewolnicą, wołem, osłem i wszystkimi rzeczami, które należą do bliźniego. Choć, trzeba poprawniej powiedzieć nie "pomiędzy” domem a resztą tego, co należało do bliźniego (mężczyzny), ale „jako część" domu bliźniego (mężczyzny), wraz z niewolnikami (i niewolnicami), wołem, osłem i wszystkim, co do niego należy. Choć dla nas i z naszej perspektywy prawodawstwo takie wydaje się niesprawiedliwe, to jednak w patriarchalnym społeczeństwie biblijnego Izraela (i wszystkich ludów starożytnych!), takie rozumienie roli kobiety było absolutnie normalne. Takie widzenie kobiety nie jest odbieraniem jej godności czy praw (czyli rodzajem przemocy, zgodnie ze wspomnianą definicją współczesną), tylko innym niż współczesne patrzeniem na kwestie społeczeństwa w ogóle. System patriarchalny dominował na całym Bliskim Wschodzie ${ }^{20}$. Biblijny Izrael na tle prawodawstwa starożytnego (np. Mezopotamii) i tak w tym względzie wydaje się łagodny - ciekawostką w tym kontekście może być fakt, że w drugiej wersji Dekalogu (zawartej w Pwt 5), żona znajduje się na początku tego przykazania (do niej jedynie odnosi się tak-

17 Por. na ten temat: Ch.B. Anderson, Women, Ideology, and Violence.

18 Na temat Dekalogu w kontekście kobiet, zob.: T. Craven, Women Who Lied for the Faith, s. 35-49; S. Hagith, Between Woman, Man and God; D. Tonelli, Il decalogo.

19 Na jego temat zob.: J. Lemański, Księga Wyjścia, s. 432-433.

20 Na temat społeczeństwa patriarchalnego w Biblii zob.m.in.: C.L. Meyers, Was Ancient Israel a Patriarchal Society?, s. 8-27; por. także: R. Radford Ruether, Feminism and Patriarchal Religion, s. 54-66. 
że czasownik „pożądać” - hebr. ${ }^{21} \prod_{T}^{21}$ ), potem dopiero dom, pole, niewolnik, niewolnica, wół, osioł i każda rzecz należąca do bliźniego ( $\mathrm{z}$ innym czasownikiem; por. Pwt 5,21). A nawet to zdanie dotyczące pożądania kobiety w Pwt stanowi osobne przykazanie, wyodrębnione specjalnym znakiem separującym poszczególne przykazania: o. W Pwt 5,21 zdanie to wygląda następująco:

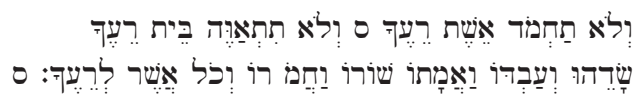

„Nie będziesz pożądał żony bliźniego twego. (0)

Nie będziesz pragnął domu bliźniego twego, ani jego pola, ani jego niewolnika, ani jego niewolnicy, ani jego wołu, ani jego osła, ani żadnej rzeczy, która należy do bliźniego twego". (o)

Być może w tej zmianie kolejności, i oddzieleniu (o) przykazania dotyczącego żony od przykazania dotyczącego domu (i innych własności bliźniego), jest obecny obraz pewnej zmiany myślenia, która dokonywała się już w samym Izraelu $^{22}$, gdzie kobieta nie jest już częścią domu ${ }^{23}$; choć trzeba powiedzieć, że oba teksty, zarówno z Wj, jak i Pwt, pozostają w zgodzie z zasadami obecnymi w obrębie społeczeństwa patriarchalnego ${ }^{24}$, gdzie kobieta była częścią rodziny, której głową był mężczyzna: była czyjąś żoną, córką, siostrą, i zawsze był mężczyzna, który miał bronić jej spraw: najpierw ojciec, a gdyby go zabrakło - brat, potem mąż, a dalej jeszcze (gdyby męża zabrakło) syn. Kobiety, które nie miały synów, a pozostawały wdowami, były najbardziej narażoną na biedę i niesprawiedliwość częścią społeczności Izraela (i innych narodów sąsiednich), ponieważ nie miały mężczyzny, który by ich obronił - stąd też w prawodawstwie biblijnego Izraela sporo miejsca poświęci się wdowom (zob. dalej), a o ich prawa będzie upominał się jeszcze Nowy Testament.

Najbardziej istotne w tym kontekście jest to, że już w Dekalogu prawo Izraela regulowało i wyraźnie potępiało przemoc wobec kobiet: zakazywało nawet pożądania (w konsekwencji mogącego prowadzić do przemocy) wobec żony (i niewolnicy) bliźniego. Ciekawe, że ten aspekt woli (o którym mówi współ-

21 J. Lemański, Księga Wyjścia, s. 432.

22 Por. np. E. Scheffler, Reflecting on (Non-)Violence in the Book of Deuteronomy in (Old Testament) Canonical Context, s. 579-596. Zob. także: J. Lemański, Księga Wyjścia, s. 432. Argumenty na korzyść pierwszeństwa Wj 20,17 przed Pwt 5,21 zob. W.H. Schmidt, Die Zehn Gebote im Rahmen, s. 132-133.

23 Por. J. Lemański, Księga Wyjścia, s. 432.

24 Por. E. Scheffler, Reflecting on (Non-)Violence in the Book, s. 579-596. 
czesna definicja przemocy) istniał już na poziomie prawodawstwa biblijnego: potępia się nie czyn, ale nawet jego pożądanie.

Pozostałe przepisy, w których wzmiankowane są kobiety, dotyczą wspomnianego już prawa karnego. Np. przepis z Wj 21,22nn chroniło kobiety w ciąży (i jej dziecko) ${ }^{25}$ : „Gdyby mężczyźni, bijąc się, uderzyli kobietę brzemienną, powodując poronienie, ale bez jakiejkolwiek szkody [kobiety], to winny zostanie ukarany grzywną, jaką na nich nałoży mąż tej kobiety, i wypłaci ją za pośrednictwem sędziów polubownych”. I dalej: „jeśli zaś ona poniesie jakąś szkodę, wówczas on odda życie za życie", a także zaraz pojawia się także słynne, inspirowane prawodawstwem babilońskim: „oko za oko, ząb za ząb, rękę za rękę, nogę za nogę, oparzenie za oparzenie, ranę za ranę, siniec za siniec"26. Prawo chroni zatem kobietę przed przypadkową przemocą ze strony mężczyzn. O grzywnę miał wnosić w jej imieniu mąż kobiety, a nie sama kobieta.

Dalej, w Wj 22,15-16, omówione są kwestie przemocy fizycznej wobec kobiet w sferze seksualnej ${ }^{27}$ : „Jeśli ktoś uwiódł dziewicę jeszcze niezaręczoną i obcował z nią, uiści rodzinie opłatę składaną przy zaślubinach i weźmie ją za żonę"; z czego mogłoby wynikać, że największą karą dla uwodziciela był sam ożenek, choć prawo akcentuje tu nie korzyść uwodziciela ani dziewczyny, ani ich odczucia, ale prawo jej ojca do rekompensaty (całość tekstu pojawia się w kontekście szkód dotyczących własności ${ }^{28}$ ). Podobnie, jak w Dekalogu, tak i tu prawo to nieco doprecyzowane jest znów w Pwt, gdzie w wersecie 22,29 dodane są jeszcze słowa (akcentujące prawa dziewczyny) „za to, że jej gwałt zadał, nie będzie jej mógł porzucić przez całe swe życie"29 (chodzi o ograniczenie prawa rozwodowego przysługującego mężczyznom na Bliskim Wschodzie). Ale tekst ten dodatkowo doprecyzowuje: „Jeśliby się ojciec nie zgodził mu jej oddać, wówczas winien zapłacić tyle, ile wynosi opłata składana przy zaślubinach dziewic", z czego wynika, że swoistą ochroną kobiety, jej reputacji i statusu miał być jej ojciec, co w społeczności patriarchalnej było regułą. A przypadki nadużyć w sferze seksualnej istniały nie tylko w biblijnym Izraelu, lecz także w innych społecznościach starożytnych ${ }^{30}$.

\footnotetext{
25 Na ten temat zob. J. Lemański, Księga Wyjścia, s. 459-465 (zwł. 462-463).

26 Por. ibidem, s. 463.

27 Por. na ich temat: D. Luciani, Violences sexuelles: comment l'Ancien Testament en parle-t-il?, s. 244-260; zob. także: J. Lemański, Księga Wyjścia, s. 468-478 (zwł. 476-477).

28 Por. J. Lemański, Księga Wyjścia, s. 476-477.

29 Por. ibidem, s. 477.

30 Por. np. Kathy L. Gaca, Martial rape, pulsating fear, and the sexual maltreatment of girls ( $\pi \alpha i ̈ \delta \varepsilon \varsigma)$, virgins ( $\pi \alpha \rho \theta \dot{\varepsilon} v o \iota)$, and women ( $\gamma v v \alpha \ddot{k} \kappa \varepsilon \varsigma)$, s. [303]-357.
} 
Potem tekst Wj 22,21-23 wspomni o ochronie grupy kobiet szczególnie narażonych na trudności - mianowicie wdowy ${ }^{31}$ (nie mające już męża, bo umarł, ale i zapewne ojca, a może brata, który miałby się nimi zająć; takie kobiety były pod szczególną ochroną prawa): „Nie będziesz krzywdził żadnej wdowy i sieroty. Jeślibyś ich skrzywdził i będą Mi się skarżyli, usłyszę ich skargę, zapali się gniew mój, i wygubię was mieczem i żony wasze będą wdowami, a dzieci wasze sierotami". Oczywiste jest, że prawo to chroniło te kobiety, które nie miały już męża ani innego mężczyzny (syna, ojca), który byłby gwarantem ich praw; jest to wyraz troski o najsłabszych członków społeczeństwa ${ }^{32}$.

W dotychczas wspomnianych przepisach zwraca uwagę jedna rzecz: widać, że wszystkie są pisane przez i dla mężczyzn. To do mężczyzn należało przestrzeganie prawa. Nie ma analogicznych przepisów w Torze ani nigdzie indziej w ST, które skierowane byłyby do kobiet („będziesz chroniła wdowca”), ponieważ to do mężczyzn należało strzeżenie prawa, także rozmaitych praw kobiet (matek, żon, sióstr i córek $)^{33}$. Wszystkie te przepisy należy rozumieć w kontekście społeczeństwa starożytnego, wpisanego w kulturę całego Bliskiego Wschodu i starożytności. Gdy redagowano Torę, taki sposób myślenia był normą, a i nadal jest właściwy dla większości społeczeństw tradycyjnych na Bliskim Wschodzie. Tak rozumiana troska o prawo nakładała na mężczyzn zdecydowanie większą odpowiedzialność także za kobiety.

Większość przepisów Tory nie dotyczy oczywiście kobiet, ale kultu, przybytku, ofiar, kapłanów (te sfery nie dotyczyły kobiet), ale ciekawe, ze nawet w Księdze Kapłańskiej, zawierającej rozmaite szczegółowe rozporządzenia dotyczące kultu, pojawiają się rozporządzenia dotyczące kobiet, będące wyrazem troski o nie. Chodzi zwłaszcza dwa duże rozdziały poświęcone w całości kobietom w Księdze Kapłańskiej: Kpł 12 i 15, zawierające przepisy dotyczące najbardziej intymnej sfery kobiet: nieczystości po porodzie (Kpł 12) i nieczystości menstruacyjnej (Kpł 15) ${ }^{34}$. Oba odnoszące się przecież wyłącznie do kobiet dotyczyły najbardziej intymnej sfery życia - ale kierowane były do mężczyzn, którzy redagowali i studiowali Torę. Ciekawe, że umieszczono je w prawodawstwie Tory, być może po to, by zwrócić uwagę na tę sferę życia kobiety (związaną

31 Na temat wdów w Biblii zob.: H.V. Bennett, Injustice Made Legal; P. Galpaz-Feller, The Widow in the Bible, s. 231-253.

32 Na temat tego tekstu zob. J. Lemański, Ksiegga Wyjścia, s. 481-487 (zwł. s. 483-484).

33 Por. w kontekście Dekalogu: A. Brenner, G.A. Lee, The Decalogue, s. 197-204. Zob. także: S. Hagith, Between Woman, Man and God.

$34 \mathrm{Na}$ temat tych tekstów zob.: B. Strzałkowska, Kobiety w świetle przepisów Księgi, s. 5-44; na temat tekstu Kpł 15 zob. studium: eadem, Rozporzadzenia dotyczace kobiet $w$ Kpt 15. 
z przekazywaniem nowego życia) i w jakimś stopniu uświadamiając mężczyznom, jak ważną jest troska o te sfery życia i jak bardzo kobiety w tym czasie, zwłaszcza ciąży, porodu, potrzebują troski. I choć z naszej perspektywy rozumiemy te teksty czasem jako dyskryminujące, czy nawet jako swoistą przemoc (bo przecież coś, co jest naturalną częścią życia kobiety staje się powodem jej nieczystości; przecież kobieta swoich naturalnych przypadłości biologicznych nie może się pozbyć, a powodowały one nieczystość) ${ }^{35}$, to w gruncie rzeczy jeśli dobrze im się przyjrzymy w kontekście społeczności starożytnej - są one raczej wyrazem troski o najbardziej intymną sferę życia kobiety, a te kierowane były także do mężczyzn ${ }^{36}$.

Także w tzw. Prawie Świętości zawartym w Kpł 17-26, są przepisy odnoszące się do kobiet, głównie w kwestiach dotyczących małżeństwa, rodziny i sfery seksualnej:

- Kpł 18 i 20 mówią o relacjach w małżeństwie oraz o relacjach intymnych między kuzynami oraz sankcjach za wykroczenia w tej dziedzinie (m.in. chodzi o zakaz obcowania płciowego z matką, macochą, siostrą, córką ojca lub córką matki, córką syna lub córką matki, synową, ciotką itd.; por. Kpł 18,1-30 $0^{37}$ oraz Kpł 20,10nn ${ }^{38}$ ) - warto zwrócić uwagę, że przepisy te znów dotyczą wyłącznie mężczyzn (!); nie ma w nich mowy o zakazie dla kobiet (by nie współżyć z bratem, ojcem, ojczymem, synem ojca lub synem matki itd.). To dlatego, że odpowiedzialność znów mieli wziąć mężczyźni. Nie znaczy to, że kobiet te rozporządzenia nie dotyczyły!

- Kpł 21,7 mówi z kolei o małżeństwie kapłana (który ma poślubić tylko „dziewicę spośród swoich krewnych”, ani wdowy, ani rozwiedzionej, ani pohańbionej, ani nierządnicy) ${ }^{39}$. Z kolei Pwt reguluje inne zwyczaje małżeńskie: Pwt 21,10-14 powie o poślubieniu (przez Izraelitę) kobiety branki (spośród jeńców); Pwt 21,15 o mężu, który ma dwie żony; natomiast Pwt 22,13nn mówi o poślubieniu dziewicy; a Pwt 24,1nn o liście rozwodowym, który może wręczyć mąż żonie (nie odwrotnie; to ten przepis, do którego odwoła się Jezus w Kazaniu na Górze); z kolei w Pwt $25,5 \mathrm{n}$ - opisane jest prawo lewiratu ${ }^{40}$.

\footnotetext{
35 Por. eadem, Kobiety w świetle przepisów Księgi, s. 5-7.

36 Por. eadem, Rozporządzenia dotyczace kobiet w Kpł 15, zwł. s. 175-182.

37 Por. A. Tronina, Księga Kapłańska, s. 262-271.

38 Por. ibidem, s. 296-306.

39 Na ten temat zob. ibidem, s. 312.

40 Na temat wybranych aspektów tego prawodawstwa Księgi Powtórzonego Prawa zob. H.C. Washington, "Lest He Die in the Battle and Another Man Take Her", s. 185-213.
} 
W każdym z wyliczonych przypadków kobieta jest przedmiotem rozporządzenia, natomiast podmiotem i podlegającym prawu jest mężczyzna.

Nieco inaczej jest $\mathrm{z}$ prawem zawartym w Pwt 22,23-29: który zawiera prawodawstwo dotyczące cudzołóstwa (hebr. נאר) - czyli współżycia z czyjąś żoną, za co groziła kara śmierci przez ukamienowanie dla obojga (w kwestii cudzołóstwa zarówno mężczyzna, jak i kobieta, ponosili odpowiedzialność) lub - w jednym tylko przypadku (oryginalnym na tle prawodawstwa Bliskiego Wschodu - tylko mężczyzna odpowiadał śmiercią (!) za taki czyn. Kara śmierci groziła obojgu wówczas, gdy cudzołóstwo nastąpiło w mieście (kobietę miano ukamienować „za to, że nie krzyczała”, mężczyznę zaś za czyn). Gdy cudzołóstwo dokonało się poza miastem - tylko mężczyzna miał być zabity: prawo domniemywa bowiem, że kobieta krzyczała, tylko nikt nie słyszał - i za czyn zostaje zabity (ponosi odpowiedzialność za oboje) tylko mężczyzna! A warto przypomnieć, że są do dziś społeczności, gdzie za samo podejrzenie cudzołóstwa kamienuje się tylko samą kobietę ${ }^{41}$. Biblia na tym tle wydaje się wręcz nowoczesna! Ciekawe, że mimo takiego prawodawstwa, czasem konsekwencję cudzołóstwa w Izraelu ponosiła sama kobieta - przykładem może być opisany w Nowym Testamencie (J 8) przypadek, gdy kobieta cudzołożna miała odpowiadać za ten czyn sama, co było w świetle prawa żydowskiego wielką niesprawiedliwością.

Gdy przeglądamy te spisy praw w tym, co odnosi się do kobiet, może nasunąć się refleksja: że oto kobiety w kontekście prawodawstwa biblijnego Izraela pojawiają się wyłącznie w kontekście sfery małżeńskiej i intymnej (nadużyć lub regulacji tej sfery życia). Czy to znaczy, że były traktowane przedmiotowo? Zapewne nie może chodzić raczej o to, że przepisy te regulują wszystkie sprawy w perspektywie mężczyzn, a w tej dziedzinie najłatwiej o różne namiętności i nadużycia. Być może chodzi także o wypełnienie pierwszego przykazania Boga, jakie otrzymuje człowiek (mężczyzna i kobieta) jeszcze w raju: bądźcie płodni i rozmnażajcie się, co może uzasadniać liczne prawodawstwo dotyczące tej sfery (w Torze istnieją przecież przepisy dotyczące sfery seksualnej zarówno kobiet, jak i mężczyzn; por. prawo Kpł 15 regulujące kwestie intymnej sfery życia mężzzyzn ${ }^{42}$ ).

41 Chodzi o społeczności tradycyjne zamieszkujące Bliski Wschód, ale i Afrykę. Na temat przemocy wobec kobiet w Afryce zob. J. Ngalula, M.-M. Kalala, Dieu dénonce et condamne les violences faites aux femmes; por. także: J.T. Fitzgerald, Domestic violence in the Ancient World, s. 101-121.

$42 \mathrm{Na}$ ich temat zob. B. Strzałkowska, Rozporzadzenia dotyczace kobiet w Kpł 15, zwł. s. $59-74$. 
Trzeba zauważyć jednocześnie, że w Torze pośród rozmaitych przepisów są też (nieliczne, ale jednak) przepisy odnoszące się do kobiet, a niezwiązane ze sferą seksualności czy małżeństwa, czy płodności); np. :

- Lb 36 opowiada o dziedziczeniu majątku przez córki;

- Pwt 22,5 mówi o zakazie noszenia ubrań męskich przez kobiety i odwrotnie („kto tak postępuje obrzydły jest dla Pana Boga swego”);

- tajemniczy przepis pojawia się w wersecie Wj 22,17: „Nie pozwolisz żyć czarownicy" (trudny do zinterpretowania przepis ${ }^{43}$ ).

Więcej przepisów dotyczących kobiet w prawodawstwie Pięcioksięgu nie ma. Nasuwa się kilka konkluzji i refleksji w kontekście tytułowego pytania: czy prawodawstwo biblijnego Izraela w jakikolwiek sposób odnosiło się do kwestii przemocy wobec kobiet lub mogło być przyczyną przemocy?

Pierwsza refleksja związana jest nie tyle z prawodawstwem, ile ze wspomnianymi przypadkami przemocy wobec kobiet i z udziałem kobiet opisanymi w Pięcioksięgu. Czy wspomniane w prawodawstwie biblijnego Izraela sankcje dotyczące poszczególnych występków były w ogóle stosowane?

Najpierw w tym, co dotyczy przemocy mężczyzn wobec kobiet: Dina zgodnie z prawem biblijnego Izraela musiała zostać poślubiona przez Sychema tak się jednak nie stało (choć planowano to zgodnie z prawem), bo bracia jej pomścili siostrę, zabijając nie tylko jej gwałciciela, ale i wszystkich z jego rodu, stosując, także obowiązującą na Bliskim Wschodzie, choć niezapisaną w prawie, zasadę odpłaty.

A w tym, co dotyczy przemocy, którą zadają kobiety? Czy sankcje dotyczą w jakimkolwiek stopniu kobiet, które zadają przemoc, nawet tę psychiczną? ${ }^{44}$ Nie ma paragrafu w prawie Izraela, która taką sytuację regulowałaby od strony kobiet, a przecież sama Biblia pokazuje, że takie sytuacje istniały. Nie ma w prawie Izraela mowy o konsekwencjach, które ponosiłaby kobieta za akt przemocy, tak jakby za przestępstwa te nie odpowiadała (poza sferą seksualną, dokładnie przy cudzołóstwie, za które kobieta miała być ukamienowana wraz z mężczyzną). Czy kobiety w ogóle nie były sądzone za czyny przemocy? Czy nie podlegały prawu? A może kobiety nie popełniały przestępstw? Albo - jeśli popełniały - to robiły to tak rzadko, że prawo o tym nie wspomina. A może za każdą kobietę i jej czyny odpowiadał mężczyzna (ojciec, mąż)? Albo prze-

43 Na jego temat zob. D.J. Bretherton, An Invitation to Murder?, s. 145-152.

44 O tym, czy kobiet dotyczyły i obowiązywały prawa Tory, zob. np. wspomniany tekst: A. Brenner, G.A. Lee, The Decalogue: Am I an Addresee [i.e. Addressee]?, s. 197-204. 
moc kobiet miała taki charakter, że nie podlegała przepisom karnym? Bo jak osądzić kobietę niewolnicę, która zaśmiewała się z żony swego pana, że ta nie może mieć dzieci? Lub tą, która w odpowiedzi na to, mając już dziecko, tamtą wygnała $z$ domu na pustynię? Albo czy córki Lota poniosły konsekwencje swego czynu? Nie! Stały się nawet matkami dwóch narodów - sąsiadów biblijnego Izraela (Ammonitów i Moabitów). Nie ma paragrafów w prawodawstwie biblijnego Izraela, które takie sytuacje by regulowały od strony kobiet. A przecież, jak sama Biblia pokazuje, że one - choć nieczęste - to jednak się zdarzały. $\mathrm{W}$ tym kontekście trzeba stanąć wobec problemu niepełności prawodawstwa biblijnego.

Kolejna więc refleksja, jaka się rodzi, to ta, by na teksty prawodawstwa biblijnego Izraela dotyczące kobiet nie patrzeć stereotypowo. Te zapisane prawa nie regulują wszystkich kwestii związanych z życiem człowieka, zarówno mężczyzny, jak i kobiety. Prawo nie regulowało wszystkich występków ani wszelkiej przemocy. Może mieć ono luki i je ma. Reguluje jedynie wybrane aspekty, i to w perspektywie tych, do których było prawo kierowane: mężczyzn. Teksty te są zapisane przez mężczyzn i dla mężczyzn; kobiety w starożytności nie zajmowały się tworzeniem ani spisywaniem prawa, a w społeczeństwie patriarchalnym odpowiedzialność przestrzegania wszelkich przepisów - co zostało ukazane spoczywała na mężczyźnie.

Co jeszcze ważniejsze, nie ma nawet w samej Biblii dowodu na to, by przepisy, które zostały omówione, były zawsze bezwzględnie stosowane. Najlepszym przykładem jest tu cudzołóstwo regulowane przepisem z Pwt. Choć groziła kara śmierci dla obojga, nigdzie w Biblii nie mamy opisu jej wykonania. Złośliwi mówią, że do zasądzenia kary śmierci potrzeba było jeszcze dwóch świadków (poza zainteresowanymi), więc trudno w sytuacji intymnej o znalezienie takich właśnie. Ale problem stosowalności prawa biblijnego Izraela i jego egzekucji pozostaje otwarty ${ }^{45}$.

W końcu, interpretując wszystkie te przepisy, choćby wydały się dziś najbardziej dziwne, niesprawiedliwe, trzeba mieć świadomość, że wpisują się one w obyczajowość ludów starożytnych i czytając je, nie powinniśmy współczesnych kategorii świata zachodniego i przyzwyczajeń przykładać do zupełnie innych czasów, innego społeczeństwa i innej obyczajowości. Społeczeństwo biblijnego Izraela było patriarchalne i przepisy zawarte na kartach Biblii odpowiadają takiemu sposobowi opisywania rzeczywistości. Jeśli ktoś oburza się na nie, widząc w nich przejaw dyskryminacji kobiet (a zatem rodzaj przemocy wobec nich), popada w tę pułapkę wspomnianą na początku: narzucając Biblii

45 Podobnie jak i w prawodawstwie ludów ościennych, np. w starożytnej Mezopotamii; zob. R. Westbrook, The Enforcement of Morals in Mesopotamian Law, s. 753-756. 
to, co sam chce widzieć, nie odczytując tego, co w niej jest. W takim podejściu narazić się można także na niebezpieczeństwo ideologizacji badań i refleksji, o którą w tematach dotyczących kobiet, a zwłaszcza przemocy wobec kobiet, czy rozmaitych form dyskryminacji jest bardzo łatwo.

\section{Zakończenie}

Przyglądając się prawodawstwu Pięcioksięgu dotyczącemu kobiet, nie widać w nich przemocy ani źródła przemocy wobec nich. Na pierwszy plan wysuwa się zdecydowanie potępienie przemocy i choć nie wszystkie przypadki są w prawie dokładnie określone sankcjami, to jednak wyraźnie teksty te nie usprawiedliwiają przemocy wobec kobiet w jakiejkolwiek postaci, a tym bardziej nie zachęcają do niej, czy to w czasach biblijnych czy później.

Gdyby porównywać sposób patrzenia na kobietę w czasach Starego i Nowego Testamentu, można dostrzec, jak chrześcijaństwo z jednej strony wpisywało się w tę samą logikę, z drugiej jak powoli zmieniało rolę i posłannictwo kobiety. Jezus, odnosząc się do prawodawstwa Tory, choćby w Kazaniu na Górze, czy w historii kobiety cierpiącej na krwotok, na nowo odczytuje zawarte w Starym Testamencie przepisy odnoszące się do kobiet. Także św. Paweł daje poznać, że „nie ma już Żyda ani poganina, nie ma już niewolnika ani człowieka wolnego, nie ma już mężczyzny ani kobiety, wszyscy bowiem jesteście kimś jednym w Chrystusie Jezusie" (Ga 3,28), czego konkretny wyraz da choćby w chrzcie pierwszego Europejczyka, którym była kobieta - Lidia (Dz 16,13nn) ${ }^{46}$. Święty Paweł w tzw. tablicach rodzinnych wyznaczy zadania także dla kobiet - prawa, które miały obowiązywać kobiety, co było w pespektywie Tory nowością (w Pięcioksięgu, jak zostało podkreślone, nie było praw i zadań dla kobiet!).

Te kwestie ostatecznie ukazują także zmianę sposobu myślenia, która dokonywała się w chrześcijaństwie, choć i judaizmie czasów późniejszych, kiedy od kobiety coraz więcej zależało. W obu tradycjach kobiety dawały przykład wierności Bogu i Jego Słowu, również tym kodyfikacjom prawnym zawartym w Pięcioksięgu.

46 Na temat św. Pawła i kobiet zob. B. Strzałkowska, „Nie ma już mężczyzny ani kobiety” (Ga 3,28), s. 137-149 (Sum.). 


\section{Bibliografia}

\section{Na temat przemocy wobec kobiet w Biblii:}

Anbar (Berstein) M., L'influence deutéronomique sur le Code de l'Alliance: le cas d'Exode 21:12-17, Zeitschrift für Altorientalische und Biblische Rechtsgeschichte 5 (1999), s. 165-166.

Fitzgerald J.T., Domestic violence in the Ancient World: Preliminary Considerations and the Problem of Wife-beating, w: Animosity, the Bible, and Us: Some European, North American, and South African Perspectives, red. J. T. Fitzgerald, F.J. van Rensburg and H. F. van Rooy, Atlanta 2009, s. 101-121.

Gaca K.L., Martial rape, pulsating fear, and the sexual maltreatment of girls ( $\pi \alpha i ̈ \delta \varepsilon \varsigma)$, virgins ( $\pi \alpha \rho \theta \dot{\varepsilon} v o l)$, and women ( $\gamma v v \alpha \ddot{k} \kappa \varepsilon \varsigma)$ in Antiquity, American Journal of Philology, 135 (2014) 3, s. [303]-357.

Kirk-Duggan Ch.A., Pregnant Passion. Gender, Sex, and Violence in the Bible, Semeia Studies. Society of Biblical Literature, Atlanta, Georgia 2003.

Luciani D., Violences sexuelles: comment l'Ancien Testament en parle-t-il?, Biblische Zeitschrift 52 (2008) 2, s. 244-260.

Ngalula J., Kalala M.-M., Dieu dénonce et condamne les violences faites aux femmes, Bible et femme en Afrique 1, Kinshasa 2005.

Reeder C.A., Wives and Daughters: Women, Sex, and Violence in Biblical Tradition, Ex Auditu 28 (2012), s. 122-141; Fragile Dignity. Intercontextual Conversations on Scriptures, Family, and Violence, red. L.J. Claassens, K. Spronk, Semeia Studies. Society of Biblical Literature 72, Atlanta 2013.

La violence envers les femmes: Concilium: Revue internationale de théologie 252 (1994) (w tym tomie m.in. artykuł: E. Schüssler-Fiorenza, La violence contre les femmes, s. 7-25 oraz I. Fischer, "Va, et sois soumise", dit l'Ange de Dieu à Agar: Répressions contre les femmes dans les textes bibliques, s. 107-114.).

Washington H.C., Violence and the Construction of Gender in the Hebrew Bible: A New Historicist Approach, Biblical Interpretation 5 (1997), s. 324-363.

Washington H.C., "Lest He Die in the Battle and Another Man Take Her": Violence and the Construction of Gender in the Laws of Deuteronomy 20-22, w: Gender and Law in the Hebrew Bible and the Ancient Near East, V.H. Matthews, Sheffield 1998 , s. 185-213.

\section{Na temat przemocy w Biblii:}

Bekkenkamp J., Sherwood Y., Sanctified Aggression: Legacies of Biblical and Post Biblical Vocabularies of Violence, Journal for the Study of the Old Testament Supplement Series 400, London 2003. 
Chrostowski W., Przemoc i gwałt w Piśmie Świętym, w: Przemoc i terror. Książka dedykowana Księdzu Profesorowi Stanisławowi Olejnikowi w 80ta rocznice urodzin i 50ta rocznice pracy naukowej, red. P. Góralczyk, J.A. Sobkowiak, Warszawa 2001, s. 89-109.

Chrostowski W., Zjawiska przemocy $i$ gwałtu $w$ Starym Testamencie jako przejawy zapośredniczenia poznania Boga, w: „Bóg jest miłościa” $(1 \mathrm{~J}$ 4,16). Studia dla Księdza Profesora Józefa Kudasiewicza w 80. rocznicę urodzin, red. W. Chrostowski, Rozprawy i Studia Biblijne 25, Warszawa 2006, s. 89-102.

Girard R., La Violence et le sacré, Paris 1972.

Lohfink N., Gewalt und Gewaltlosigkeit im Alten Testament, Quaestiones disputatae 96, Freiburg im Breisgau 1983.

Pikor W., Bóg wobec przemocy człowieka $w$ Rdz 1-11, Collectanea Theologica 73 (2003) 3, s. 11-31.

Römer T., Dieu obscur: le sexe, la cruauté et la violence dans l'Ancien Testament, Essais bibliques 27, Genève 1996.

La violència en la Bíblia, red. d’Armand Puig i Tàrrech, Scripta Biblica 9, Associació Bíblica de Catalunya, Tarragona 2009.

Wénin A., Au-delà de la violence, quelle justice? Réflexions à partir du Premier Testament, Revue théologique de Louvain 34 (2003) 3, s. 433-456.

\section{Inne:}

Bartchy Scott S., Slavery (Greco-Roman New Testament), w: The Anchor Bible Dictionary t. VI, red. D.N. Freedman, New York, Doubloeday 1992, s. 65-73.

Bennett H.V., Injustice Made Legal. Deuteronomic Law and the Plight of Widows, Strangers, and Orphans in Ancient Israel, Grand Rapids 2002.

La Bibbia di Gerusalemme, Bologna 1984 (por. Presentazione, s. 5-7).

Brenner A., G.A. Lee, The Decalogue: Am I an Addresee [i.e. Addressee]?, w: Exodus and Deuteronomy, Minneapolis 2012, s. 197-204.

Bretherton D.J., An Invitation to Murder? A Re-Interpretation of Exodus 22:18 "You Shall Not Suffer a Witch to Live", Expository Times 116 (2005), s. 145-152.

Cardellini I., Die biblischen "Sklaven”-Gesetze im Lichte des keilschriftlichen Sklavenrechts, Bonn 1981.

Craven T., Women Who Lied for the Faith, w: Justice and the Holy, red. W. Harrelson, Atlanta 1989, s. 35-49.

Dandamayev M.A., Slavery (Ancient Near East/ Old Testament), w: The Anchor Bible Dictionary, t. VI, red. D.N. Freedman, New York, Doubloeday 1992, s. 58-65.

David M., The Codex Hammurabi and its Relation to the Provisions of Law in Exodus, w: Oudtestamentische Studiën, t. VII (praca zbiorowa), Leiden 1950, s. 149-178.

Galpaz-Feller P., The Widow in the Bible and in Ancient Egypt, Zeitschrift für die alttestamentliche Wissenschaft 120 (2008), s. 231-253.

Haag E., Le péché des origines et l'héritage de la violence à la lumière de l'historie biblique des origines, w: R. Gérard, Tradition et renouvellement en théologie, Centre de Recherche Pensée chrétienne et langage de la foi, Metz 1990, s. 13-31. 
Hagith S., Between Woman, Man and God: A New Interpretation of the Ten Commandments, Journal for the Study of the Old Testament Supplement Series 401, London 2004.

Joshel S.R., Slavery in the Roman World, Cambridge Introduction to Roman Civilization, Cambridge, New York, Melbourne 2010.

Kopaliński W., Słownik eponimów czyli wyrazów odimiennych, Warszawa 1996.

Lemański J., Księga Wyjścia. Wstęp - przekład z oryginału - komentarz, Nowy Komentarz Biblijny. Stary Testament 2, Częstochowa 2009.

Mendelsohn I., Slavery in the Ancient Near East : A Comparative Study of Slavery in Babylonia, Assyria, Syria, and Palestine from the Middle of the Third Millennium to the End of the First Millennium, New York 1949.

Meyers C.L., Was Ancient Israel a Patriarchal Society?, Journal of Biblical Literature 133 (2014) 1, s. 8-27.

Radford Ruether R., Feminism and Patriarchal Religion: Principles of Ideological Critique of the Bible, Journal for the Study of the Old Testament 22 (1982), s. 54-66.

Scheffler E., Reflecting on (Non-)Violence in the Book of Deuteronomy in (Old Testament) Canonical Context, Old Testament Essays 27 (2014) 2, s. 579-596.

Schmidt W.H., Die Zehn Gebote im Rahmen alttestamentlicher Ethik. Anmerkungen zum gegenwärtigen Stand der Forschung: H. Graf Reventlow (Hg.), Weisheit, Ethos und Gebot. Weisheits- und Dekalogtraditionen in der Bibel und im frühen Judentum, Neukirchen-Vluyn 2001, s. 132-133.

Strzałkowska B., Rozporządzenia dotyczące kobiet w Kpł 15, Rozprawy i Studia Biblijne 20, Warszawa 2006.

Strzałkowska B., „Nie ma już mężczyzny ani kobiety” (Ga 3,28). Rzecz o kobietach u św. Pawła, [w:] Życie, apostolat i dziedzictwo Pawła z Tarsu, zebr. i oprac. G. Szamocki, Christianitas Antiqua. Commentationes III, Gdańsk 2010, s. 137-149 (Sum.).

Strzałkowska B., Kobiety w świetle przepisów Księgi Kapłańskiej, Collectanea Theologica 83 (2013) 2, s. 5-44.

Tonelli D., Il decalogo: uno sguardo retrospettivo, Scienze religiose. Nuova serie 25, Bologna 2010.

Tronina A., Księga Kapłańska. Wstęp - przekład z oryginału - komentarz, Nowy Komentarz Biblijny. Stary Testament 3, Częstochowa 2006.

Westbrook R., The Enforcement of Morals in Mesopotamian Law, Journal of the American Oriental Society 104 (1984), s. 753-756.

Wiedemann Th., Greek and Roman Slavery, Baltimore 1981.

World Report on Violence and Health, red. E.G. Krug, L.L. Dahlberg, J.A. Mercy, A.B. Zwi, R. Lozano, World Health Organization, Genewa 2002 (na podstawie m.in. dokumentu WHO z 1996 roku: Violence: a Public Health Priority. WHO Global Consultation on Violence and Health,).

Wright D.P., The Laws of Hammurabi as a Source for the Covenant Collection (Exodus 20:23-23:19), Maarav 10 (2003), s. 11-87. 


\section{Poszczególne teksty:}

$\operatorname{Rdz} 4$

Boyer F., "Depuis le sang d'Abel". Fraternité, violence et transcendance, w: P. Beauchamp, Ouvrir les écritures, Paris 1995, s. 53-64.

Brandscheidt R., Kain und Abel: Die Sündenfallerzählung des Jahwisten in Gen 4,1-16. Prof. Dr. Ernst Haag zum 65. Geburtstag, Trierer Theologische Zeitschrift 106, Trier 1997.

Chrostowski W., Zawsze istnieje możliwość poprawy (Rdz 4,2b-8), Przegląd Powszechny 244 (1984) nr 7-8 (755-756), s. 98-111(Rés.).

Chrostowski W., „Gdzie jest brat twój, Abel?” (Rdz 4,9). Biblijne spojrzenie na przemoc i gwatt, w: Agresja i przemoc w świetle nauk przyrodniczych i humanistycznych, red. M. Machinek, Biblioteka Wydziału Teologii Uniwersytetu WarmińskoMazurskiego 8, Olsztyn 2002, s. 195-209.

Chrostowski W., U źródeł przemocy: Kain i Abel (Rdz 4,1-16), Studia Bobolanum 5 (2005) 2, s. 5-19 (Sum.);

Gibert P., Lespérance de Caïn. La Bible et la violence, Paris 2002.

Gondar Pérez D., Estudio exegético de Gn 4,1-16. Extracto de la Tesis Doctoral presentada en la Facultad de Teología de la Universidad de Navarra, Excerpta e Dissertationibus in Sacra Theologia 56 (2010), s. 5-75.

Gondar Pérez D., Caín, Abel y la sangre de los justos : Gn 4,1-16 y su recepción en la Iglesia primitiva, Colección teológica. Facultad de teología, Universidad de Navarra 131, Pamplona 2014.

Heyde H., Kain, der erste Jahwe-Verehrer: Die ursprüngliche Bedeutung der Sage von Kain und ihre Auswirkungen in Israel, Arbeiten zur Theologie: I. Reihe 23, Stuttgart 1965.

Janowski B., Jenseits von Eden: Gen 4,1-16 und die nichtpriesterliche Urgeschichte, w: A. Lange, Die Dämonen - Demons, Tübingen 2003, s. 137-159.

Lemański J., Grzech rodzi się w sercu człowieka (Rdz 4,1-16), Studia Koszalińsko-Kołobrzeskie. Filozofia - Teologia - Historia Kościoła 9 (2004), s. 33-51.

Łach S., Problemy w relacji biblijnej o Kainie i Ablu (Rdz 4,1-17), Roczniki Teologiczno-Kanoniczne 7 (1960) 3, s. 13-38 (Rés.).

Peels E., The world's first murder: violence and justice in Genesis 4:1-16, w: Animosity, the Bible, and us : some European, north American, and South African perspectives, red. J.T. Fitzgerald, F.J. van Rensburg and H.F. van Rooy, Society of Biblical Literature, Atlanta 2009, s. 19-39.

Walter D., Im Zeichen Kains: Gewalt und Gewaltüberwindung in der Hebräischen Bibel, Evangelische Theologie 64 (2004), s. 252-267.

Wénin A., Caïn: un récit mythique pour explorer la violence, w: B.V. Collado, Palabra, prodigio, poesía, Pontificio Istituto Biblico, Roma 2003, s. 37-53.

Zwilling A.-L., Caïn versus Abel (Gn 4,1-16), w: Analyse narrative et Bible, red. C. Focant, Leuven 2005, s. 507-516. 
$\operatorname{Rdz} 9$

Adamczyk D., Upadek Chama i jego skutki na podstawie Rdz 9,18-29, Seminare. Poszukiwania Naukowo-Pastoralne 30 (2011), s. 7-15, Sum.

Cappelletto G., Violenza in societa e in famiglia (Gn 6,1-4 e 9,18-29), Parole di vita 52 (2007)5, s. 4-12.

Chrostowski W., Przekleństwo Kanaana (Rdz 9,20-27) - nieudana próba zdobycia zabronionej dominacji, Przegląd Powszechny 245 (1984) nr 11 (759), s. 169-183 (Rés.).

\section{$\operatorname{Rdz} 19$}

Grossman J., "Associative meanings" in the character evaluation of Lot's daughters, The Catholic Biblical Quarterly 76 (2014)1, s. 40-57.

Jackson M., Lot's Daughters and Tamar as Tricksters and the Patriarchal Narratives as Feminist Theology, Journal for the Study of the Old Testament 98 (2002), s. 29-46.

\section{$\operatorname{Rdz} 34$}

Andiñach P.R., Dina, una mujer víctima de violencia sexual y étnica: estudio preliminar de Génesis 34, Revista Bíblica 66 (2004)1, s. 37-52.

Bechtel L.M., What if Dinah is not Raped? (Genesis 34), Journal for the Study of the Old Testament 62 (1994), s. 19-36.

Cook J.E., Rape and Its Aftermath in Genesis 34, Bible Today 44 (2006), s. 209-214.

Hepner G., The Seduction of Dinah and Jacob's Anguish Reflect Violations of Contiguous Law of the Covenant Code, Estudios Bíblicos 62 (2004), s. 111-135.

Noble P., A "Balanced" Reading of the Rape of Dinah: Some Exegetical and Methodological Observations, Biblical Interpretation 4 (1996)2, s. 173-204.

Shemesh Y., Rape is Rape is Rape: the Story of Dinah and Shechem (Genesis 34), Zeitschrift für die alttestamentliche Wissenschaft 119 (2007)1, s. 2-21.

Slawik J., O przemocy $w$ Starym Testamencie. Problemy interpretacyjne i literackokrytyczne Rdz 34, Roczniki Teologiczne 53 (2011) 1-2, s. 31-68 (Zsf.).

Van Wolde E., The Dinah Story: Rape or Worse?, Old Testament Essays 15 (2002), s. 225-239. 